\section{HUBUNGAN SENSORI INTEGRASI PADA PERMEN KARET UNTUK MENINGKATKAN DAYA INGAT}

\author{
'Edelliawan Ardityo* \\ ${ }^{2}$ Umi Kalsum
}

1,2Fisioterapi, Politeknik Kesehatan

Kementerian Kesehatan Surakarta

*Email : Edell.fisio@gmail.com

Abstrak. Tujuan dari penelitian ini adalah untuk mengetahui efek dari menguyah permen karet dengan konsep sensory integrasi yang diterima oleh reseptor rasa pada lidah untuk meningkatkan daya ingat dan konsentrasi. Penelitian dilakukan dengan membandingkan mahasiswa yang menguyah permen karet dan tidak menguyah permen karet, kemudian mereka diberikan tes berupa tes visual dan tes auditori. Dari tes visual didapatkan peningkatan sebanyak $11,8 \%$ dan tes auditori sebanyak 0,01\% pada mahasiswa yang menguyah permen karet. Kesimpulan dari penelitian ini yaitu aktifitas menguyah permen karet dapat meningkatkan memori pendek, kewaspadaan serta konsentrasi. Namun harus diketahui pula bahwa permen karet tidak lepas dari efek buruknya.

Kata Kunci: Daya Ingat, Sensory Integrasi, Permen Karet

\section{INDONESIAN JOURNAL OF FUNDAMENTAL SCIENCES (IJFS)}

\section{E-ISSN: 2621-6728 \\ P-ISSN: 2621-671X}

Submitted: December $3^{\text {th }}, 2017$

Accepted : January, $24^{\text {th }}, 2018$

Abstract. This study aims to know the effect of chewing gum with the concept of sensory integration received by taste. receptors on the tongue to improve memory and concentration. The study was conducted by comparing students who chewed gum and did not chew gum, and then they were given tests in the form of visual tests and auditory tests. From the visual tests found an increase of $11.8 \%$ and auditory tests by $0.01 \%$ in students who chew gum. The conclusion of this research is that chewing gum activity can improve short memory, alertness and concentration. But it must be known also that chewing gum is not free from the bad effects 


\section{PENDAHULUAN}

Proses mengingat merupakan suatu sirkuit yang melibatkan banyak aspek, sehingga jalur lintasan dari loncatan-loncatan saraf dapat dikonduksikan, kemudian apabila telah dibentuk jalur lintasan maka akan terbentuk jalur baru/terfasilitasi yang dikenal sebagai jejak memori. Otak menyimpan informasi dalam bentuk konsep bukan kata demi kata.

Konduksivitas loncatan listrik saraf akan terbentuk melalui stimulus yang diberikan pada reseptor pada ujung-ujung saraf. Stimulus yang diberikan dapat berbagai bentuk stimulus seperti audio, visual, mekanis, maupun kimiawi.Pada tubuh manusia dapat ditemukan berbagai reseptor yang dapat menerima stimulus tersebut, Gangguan memori yang dialami merupakan adanya disintegritas antar konduktivitas saraf sehingga tidak terciptanya ataupun menghilangnya jalur lintasan sehingga loncatan listrik saraf yang terbentuk menjadi kacau dan berakibat gagalnya otak untuk memproses informasi suatu konsep yang ada. Dalam konsep sensori integrasi stimulus-stimulus yang diberikan akan diolah dalam suatu bentuk informasi sensorik dan di bentuk suatu respons oleh otak sesuai kebutuhannya. Mengunyah permen karet memiliki banyak manfaat disela-sela aktivitas.

Permen karet berdampak pada peningkatan memori jangka pendek, rileksasi, menyegarkan mulut, mengurangi plak gigi, pengganti rokok dan netralisasi asam lambung. Pada proses mengunyah permen karet terdapat beberapa mekanisme, yaitu mekanisme mekanis dan kimiawi, sehingga pada mekanisme tersebut menimbulkan stimulus-stimulus yang akan dikonduksikan ke otak dari beberapa sumber yang kemudian akan diproses dan diintergrasikan diotak.

\section{LANDASAN TEORI}

Memory pada manusia tidak hanya menyimpan informasi dari apa yang telah dialaminya saja, tetapi juga termasuk kemampuan untuk menerima, menyimpan, dan menimbulkan kembali apa yang dialaminya (Walgito, 1994). Proses memory yang dikembangkan oleh Richard Atkinson dan Richard Shiffrin (1968) meliputi proses encoding, storage, dan retrieval. Memori sensori yaitu suatu system memori yang dirancang untuk menyimpan informasi yang diterima dari reseptor (mata, telinga, bau, rasa dan rabaan) dalam waktu yang singkat. Menurut Bailey ( 1989), sistem storage dalam memori jangka pendek terdiri da ri penyimpan display visual atau spasial dan penyimpan display verbal atau auditori.

Berdasarkan jangka waktu dan tingkat penggunaannya, terdapat 2 (dua) jenis memori yaitu memori jangka pendek (Short Term Memory) dan memori jangka panjang (Long Term Memory). Memori jangka pendek digunakan untuk informasi yang temporer, biasanya dalam bebe rapa detik. Secara konseptual, memori jangka pendek merupakan penyimpan informasi yang aktif, sedangkan memori jangka 
panjang merupakan penyimpanan informasi yang relatif pasif. Memori jangka pendek merupakan gerbang dari memori jangka panjang.

Sensory Integrasi merupakan proses pengolahan informasi yang diterima oleh mata, telinga, kulit, mulut, dan rasa yang sesuai kemudian dikirim ke otak. Proses ini berlangsung dalam berbagai sistem sensory (Horrowitz \& Rots, 2007:3). Sedangkan menurut Mirza (2008), Sensory Integrasi merupakan suatu teori yang menjelaskan proses biologis pada otak untuk mengolah berbagai informasi sensorik, dan mempergunakannya dengan baik (Rahmadani, 2013:1). Sensory Integrasi merupakan proses neurologis dalam mengatur informasi yang kita terima dari tubuh kita dan dari dunia sekitar kita untuk digunakan dalam kehidupan sehari-hari. SI ini terjadi di dalam sistem syaraf pusat, yang terdiri dari sel-se syaraf yang tak terhitung banyaknya, di dal am jaringan syaraf tulang belakang dan di dalam otak.

(Kranowitz, 44: 1998).

Studi terbaru mengenai kegiatan menguyah permen karet (mastikasi) menunjukkan bahwa penguyahan membantu untuk mempertahankan fungsi kognitive di hippocampus, suatu wilayah sistem saraf pusat penting untuk memory spasial dan belajar. Penelitian dari University of Cardiff (seperti yang ditunjukkan pada www.sciencedaily.com) menunjukkan bahwa mengunyah permen karet dapat memperpanjang rentang konsentrasi. Mengunyah permen karet bisa mendapatkan keuntungan beberapa daerah kognisi, tetapi hasilnya paling signifikan dengan memori jangka pendek. Dalam tes ilmuwan menemukan bahwa kemampuan untuk mengingat kata-kata teringat ditingkatkan dengan 35\%. Tidak ada alasan yang diketahui mengapa permen karet meningkatkan memori jangka pendek, tetapi dua hipotesis kembali terjadi adalah bahwa, pertama, permen karet menimbulkan detak jantung, yang menyebabkan lebih banyak oksigen dan nutrisi yang dipompa ke otak. Kedua permen karet memicu produksi insulin, yang merangsang bagian otak yang terlibat dengan memori. Ketika orang mengunyah, tubuh melepaskan insulin, yang merupakan respon bersyarat yang terjadi dalam mengantisipasi makan

Menguyah permen karet yang memiliki tekstur kenyal meningkatkan kerja otot rahang sehingga meningkatkan denyut nadi, peningkatan denyut nadi memfasilitasi banyaknya aliran darah yang berikatan dengan nutrisi dan oksigen masuk otak sehingga otak dapat bekerja dengan baik, konsentrasi meningkat. Selain itu rasa yang dihasilkan permen karet akan diterima oleh reseptor dilidah guna merelease enzim pada mulut. Enzim yang di release mengakibatkan adanya vasodilatasi pada sistem sirkulasi sehingga terjadi peningkatan aliran darah pada otak. Semakin meningkat aliran darah semakin banyak pula asupan oksigen yang diterima otak.

Permen karet yang dipilih yaitu jenis xylitol, permen ini memiliki manfaat untuk kesehatan gigi dan mulut, pemanis yang dihasilkan seperti rasa gula tebu namun rendah kalori dan lambat diserap tubuh sehingga aman bagi penderita diabetes 
mellitus. Xylitol diabsorbsi secara lambat dan hanya sebagian yang dimetabolisme, maka nilai kalorinya 40\% lebih kecil dari kelompok karbohidrat yang lainnya.

\section{METODE PENULISAN}

Penelitian ini dilakukan dengan menguji secara visual dan auditori yang dilakukan dengan objek penelitian sejumlah 89 mahasiswa dengan rentang usia 1723 tahun. Percobaan ini merupakan suatu perbandingan dari efek menguyah permen karet dan tidak menguyah permen karet pada peningkatan daya ingat. Sebelum melakukan penelitian, Peneliti menjelaskan mekanisme, dan tujuan dari penelitian. Kemudian peneliti membagikan permen karet kepada setengah dari objek penelitian lalu diminta untuk menguyah permen karet selama 10 menit untuk merangsang aktivasi pada hippocampus.

Pada pengujian pertama berupa tes visual, percobaan ini bertujuan untuk memeriksa efek dari permen karet pada memori jangka pendek dan konsentrasi, dan lebih terfokus pada aspek visual. Seluruh objek penelitian diminta untuk mengingat angka acak yang telah ditampilkan pada proyektor selama 20 detik. Angka acak dimulai dari 3 digit kemudian secara bertahap meningkat sampai 11 digit sesuai dengan tingkat kesulitan. Hasil penelitian ditunjukkan oleh grafik 1.

Percobaan kedua berupa tes auditori bertujuan untuk memeriksa efek dari permen karet pada kewaspadaan / konsentrasl, dan lebih terfokus pada aspek auditori. Objek penelitian yang diberi permen karet diminta untuk terus menguyah selama penelitian berlangsung. Dalam penelitian ini peneliti membaca sebuah urutan 20 angka acak mulai dari 1 sampai 9, dan objek penelitian harus melihat berapa kali peneliti telah membaca keluar ganjil, diikuti oleh bilangan genap, diikuti oleh jumlah ganjil. Proses ini dilakukan dengan 4 urutan yang berbeda, Dalam percobaan ini 19 siswa tidak mampu membaca semua 4 urutan karena sakit, dan guru selesai membaca final 2 urutan. Satu kelas tidak mampu melakukan tes mendengar dengan baik.

\section{HASIL DAN PEMBAHASAN}

Setelah melakukan penelitian didapatkan penilaian seperti pada grafik dibawah. Garis dengan warna hijau menunjukkan hasil dari test visual, sedangkan garis hitam menunjukkan hasil dari test auditory. Data menunjukkan bahwa objek penelitian dengan permen karet adalah lebih besar dari siswa tidak makan permen karet 


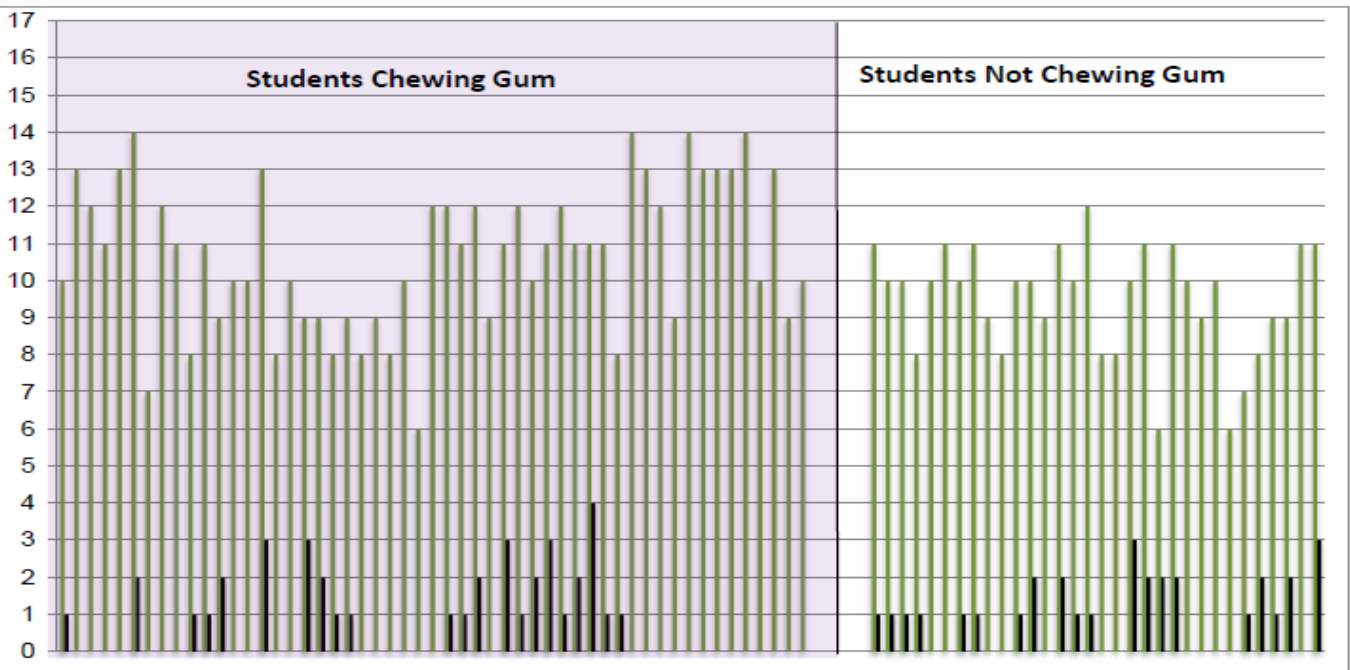

Grafik 1. Hasil Perbandingan dari objek penelitian dari aspek visual dan auditory

\section{Test Visual}

Data di bawah ini menunjukkan bahwa mean dari objek penelitian mengunyah dan tidak mengunyah permen karet dalam uji visual . Grafik menunjukkan bahwa objek penelitian permen karet memiliki rata-rata yang lebih tinggi dari objek penelitian yang tidak menguyah permen karet. Ini mungkin dianggap untuk memperkuat hipotesis bahwa permen karet dapat memiliki efek menguntungkan pada otak sejauh ingatan jangka pendek yang bersangkutan yang ditujukan terhadap memori jangka pendek dan konsentrasi.

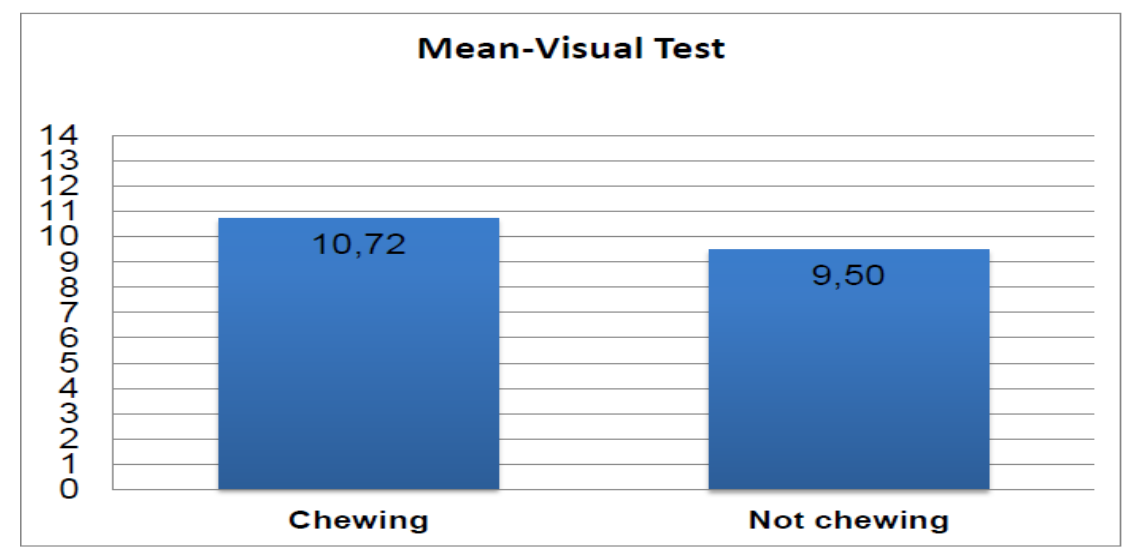

Grafik 2. Hasil Rata-rata Tes Visual

Standard deviation

Students with gum Students without gum

$=1.9940 \quad=1.5399$

$=1.99(2$ d.p $) \quad=1.54(2$ d.p $)$

Dari grafik distribusi frequensi dan deviasi menunjukkan standar bahwa data pada objek yang menguyah permen karet lebih menyebar daripada objek yang tidak menguyah permen karet. Perbedaan dari presentase tersebut yaitu sebanyak $11,8 \%$. 


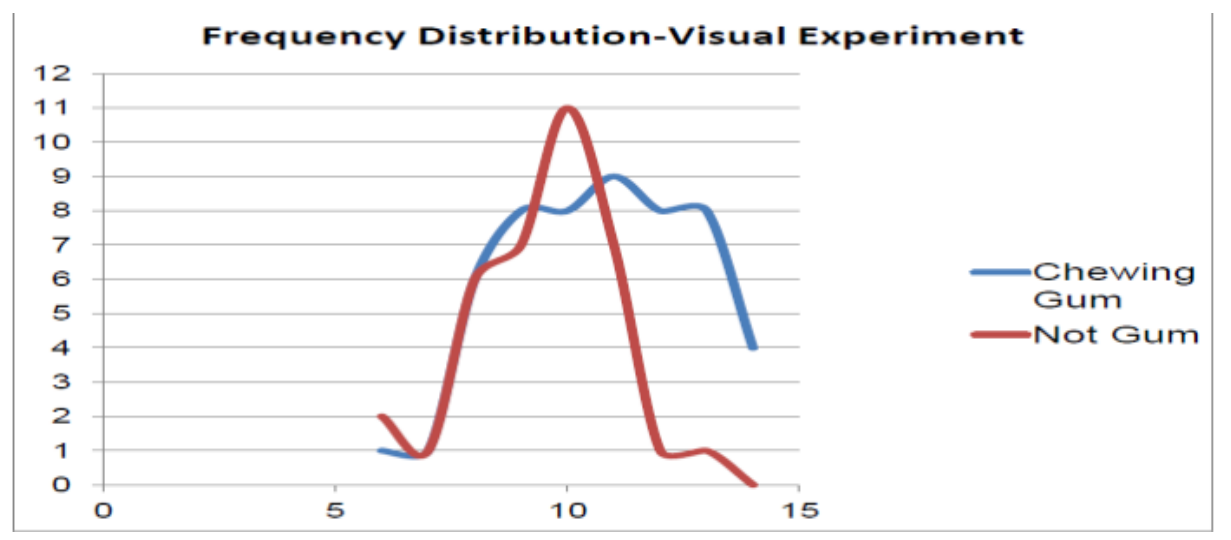

Grafik 3. Distribusi Frequensi pada percobaan visual.

\section{Tes Auditori}

Grafik dibawah merupakan hasil rata-rata objek penelitian menguyah permen karet dan tidak menguyah permen karet pada tes auditori menunjukkan bahwa objek dengan permen karet memiliki rata-rata lebih tinggi dari objek yang tidak menguyah permen karet. Namun perbedaan rata-rata hanya 0,01\%.

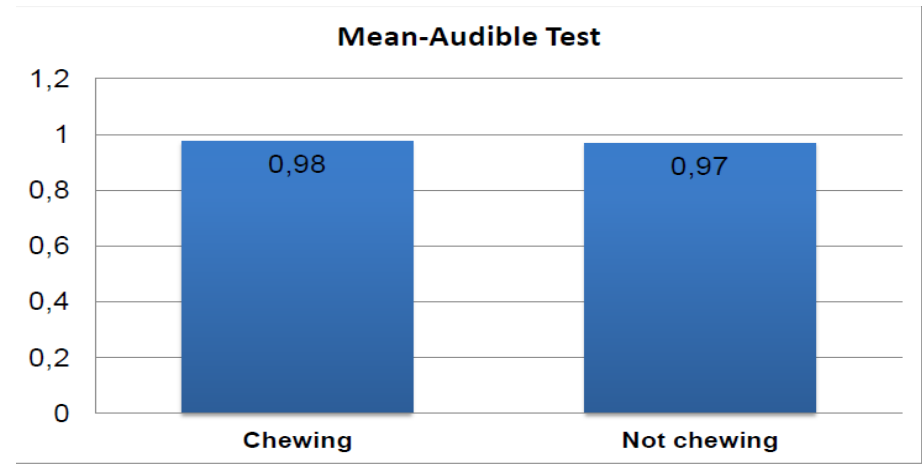

Grafik 4. Hasil Rata-rata Tes Auditori

Standard Deviation

Students with gum Students without gum

$$
\begin{array}{ll}
=1.1206 & =0.9327 \\
=1.12(2 \text { d.p }) & =0.93(2 \text { d.p })
\end{array}
$$

Grafik dibawah merupakan distribusi frequensi dan deviasi menunjukkan standar bahwa data objek dengan permen karet sangat sedikit lebih menyebar, dengan standar deviasi sedikit lebih besar. Perbedaan yang sangat minimal tersebut dapat disebabkan oleh dorongan yang singkat dari permen karet yang telah memudar pada saat tes kedua, sehingga efek dari menguyah permen karet tersebut sudah tidak maksimal. 


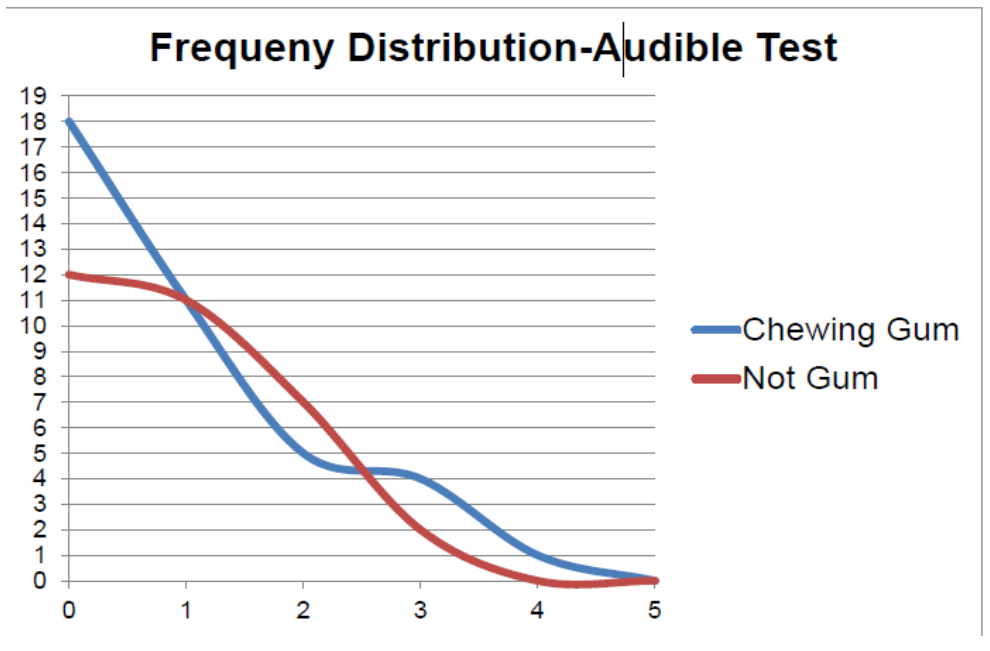

Grafik 5. Distribusi Frequensi Tes Auditori

\section{KESIMPULAN}

Dari penelitian yang telah dilakukan dengan membandingkan objek penelitian berjumlah 89 orang, setengah dari mereka diminta untuk menguyah permen karet dan setengahnya lagi tidak menguyah permen karet dengan melakukan tes visual dan tes auditori didapatkan hasil bahwa objek dengan menguyah permen karet memiliki hasil lebih tinggi dari yang tidak menguyah permen karet. penelitian menunjukkan bahwa mengunyah mungkin bisa membantu untuk meningkatkan memori jangka pendek, kewaspadaan dan konsentrasi karena peningkatan insulin, dan kadar darah di otak. Terdapat kenaikan sebesar $11,8 \%$ pada saat tes visual dan $0,01 \%$ saat tes auditori. Namun terlepas dari itu, permen karet juga memiliki efek buruk sehingga kita harus bisa memilih permen karet yang baik.

\section{UCAPAN TERIMA KASIH}

Dalam penelitian ini peneliti ingin mengucapkan banyak terima kasih kepada seluruh objek penelitian yang terdiri dari prodi DIV Fisioterapi semester $V$ dan Himpunan Mahasiswa Jurusan Fisioterapi. Selain itu ucapan terima kasih kami tujukan kepada pembimbing kita Ibu Jasmine SST.FT, SKM dan teman yang mengikuti kegiatan ini juga Onesa Destaranai dan Aprillita Asmara.

\section{DAFTAR PUSTAKA}

C. Huayue, L. Mitsuo, O. Minoru, K. Kin-Ya. 2015. Chewing Maintains HippocampusDependent Cognitive Function, International Journal of Medical Sciences, vol 12.

H. Niccolo, S5ena, Luxembourg. 2010 Chewing Gum On Adolescents, European School Luxembourg. 
Hidayati Nina, dkk. 2014. Efek Pengunyahan Permen Karet Yang Mengandung Xylitol Terhadap Peningkatan Ph Saliva, Fakultas Kedokteran Universitas Lambung Mangkurat Banjarmasin, Vol II, 2014

Kurnia. Lisa, Handajani. Resky. 2011. Efek Pengunyahan Permen Karet Gula dan Xylitol terhadap Status Saliva, Fakultas Kedokteran Universitas Gajah Mada.

Kurniawati. Indah, Iwan. Budi. 2011. Efek Mengunyah Permen Karet Terhadap Peningkatan Memori Jangka Pendek Dengan Menggunakan 3 Metode, Fakultas Kedokteran Universitas Kristen Maranata; Bandung.

Patching, Geoffrey. 2012. Does chewing gum affect short-term memory?,Institute of psychology LUNDS University.

T. Lara, K. Janneke. 2012. Gum Chewing and Cognition: An Overview. Department of Clinical and Developmental Neuropsychology, University of Groningen, 2012 